Dept. of Food Hygiene, Port-Said Lab.,

Animal Health Research Institute, Dokki, Giza, Egypt.

\title{
EFFECT OF THERMAL PROCESSING ON COLIFORMS IN MINCED BEEF AND THEIR PUBLIC HEALTH SIGNIFICANCE IN PORT-SAID CITY \\ (With 4 Tables and One Figure)
}

\section{HASSAN EL-S.M. FARAG and NAHLA T. KORASHY* \\ * Dept. of Microbiology, Port-Said Lab., Animal Health Research Institute, \\ Dokki, Giza, Egypt. (Received at 19/12/2006)

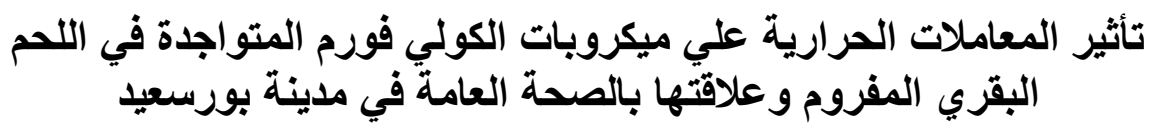 حسن السبإ محد فرج ، نـلة طه عبل الجواد قرشي}


في دراسة لتحديد مدي تأثير المعاملات الحر ارية علي ميكروبات الكولي فورم المتو اجدة في

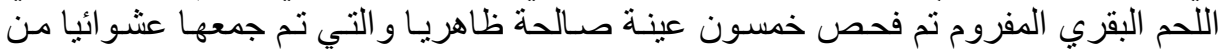

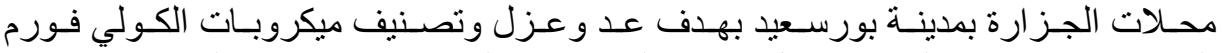

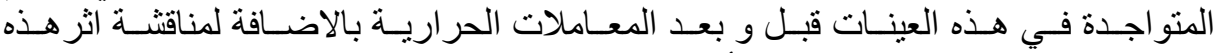

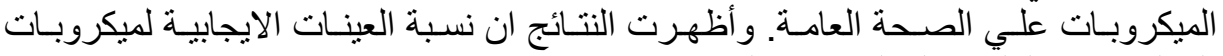

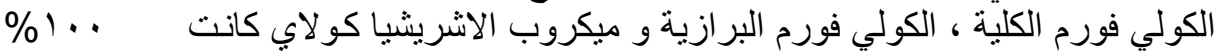

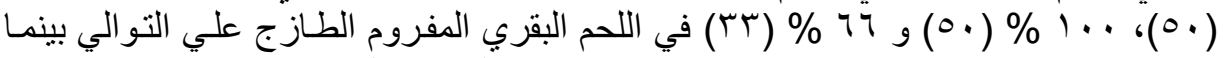

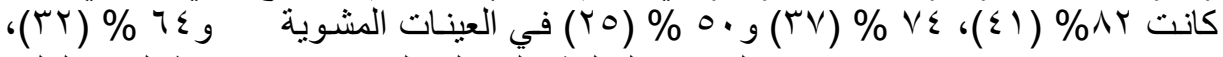

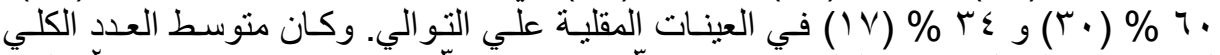

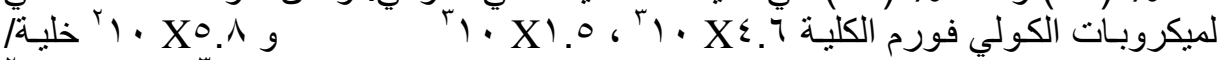

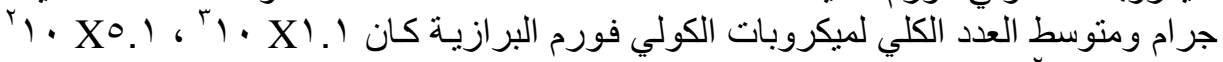

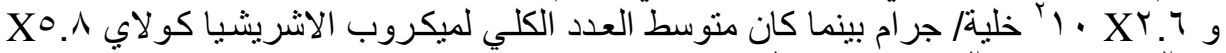

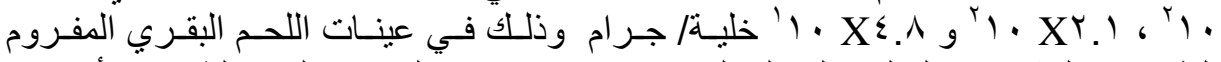

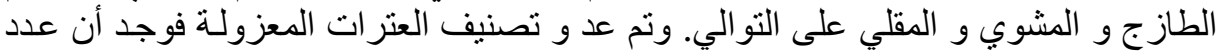

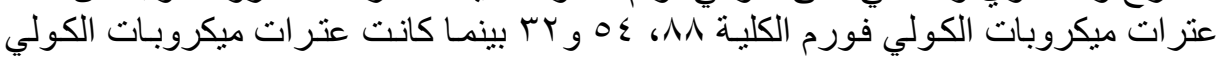

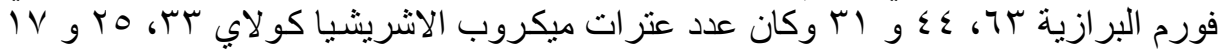

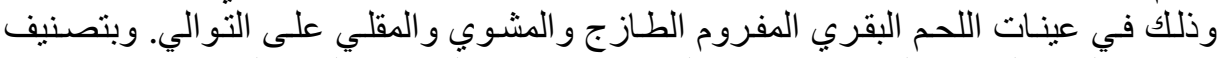

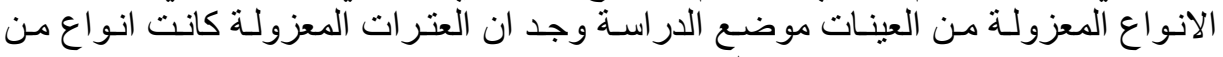

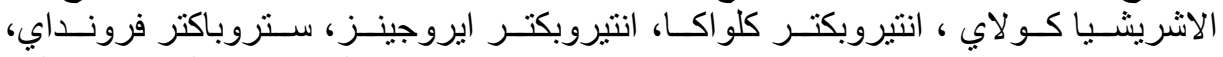

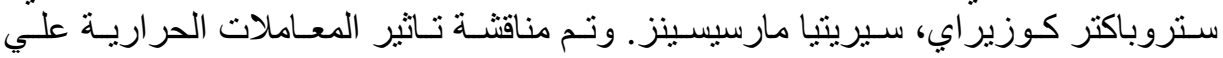
ميكروبات الكولي فورم المتو اجدة في عينات اللحم البقري المفروم موضع الثين الدراسة.

\section{SUMMARY}

Fifty samples of apparently healthy minced beef were randomly purchased from butcher's shops of Port-Said city. The samples were examined for enumeration, isolation and identification of total coliforms, fecal coliforms and Escherichia coli before and after thermal treatment. The incidence of positive fresh minced beef samples for total coliform, fecal coliform and Escherichia coli were 100\% (50), 100\% (50) and $66 \%$ (33), while that of roasting samples were $82 \%$ (41), 74\% (37) and $50 \%$ (25) but the incidence of pan frying minced beef samples were $64 \%$ (32), 60\% (30) and 34\% (17) respectively. The mean values of the total coliform counts were $4.6 \times 10^{3}, 1.5 \times 10^{3}$ and $5.8 \times 10^{2} \mathrm{MPN} / \mathrm{g}$ and that of fecal coliform counts were $1.1 \times 10^{3}, 5.1 \times 10^{2}$ and $2.6 \mathrm{X} 10^{2} \mathrm{MPN} / \mathrm{g}$ in fresh, roasting and pan frying minced beef respectively. Meanwhile, the mean values of the Escherichia coli counts were $5.8 \times 10^{2}, 2.1 \times 10^{2}$ and $4.8 \times 10^{1} \mathrm{MPN} / \mathrm{g}$ in fresh, roasting and pan frying minced beef respectively. The numbers of total coliform isolates were 88, 54 and 32 and that of fecal coliform were 63, 44 and 31 and the number of Escherichia coli isolates were 33, 25 and 17 for fresh, 
roasting and pan frying minced beef samples respectively. The bacterial isolates in the examined samples were identified as Escherichia coli, Enterobacter cloacae, Enterobacter aerogenes, Citrobacter freundii, Citrobacter koseri and Serratia marcescens. The effect of thermal processing on total and fecal coliforms and Escherichia coli in the examined samples were discussed.

Key words: Meat products, minced beef, coliforms, thermal processing

\section{INTRODUCTION}

Minced beef is the largest selling and popular beef items in most markets. Besides to their palatability it has very high value protein and valuable quantities of B vitamins (Kalalou et al., 2004).

Minced meat provides a favorable environment for the growth of bacteria which normally found on the meat surface. These bacteria were distributed throughout the entire product during grinding and mixing processes used in fabrication of minced meat. Also minced meat may be subjected to the contamination directly by coliforms group from the faecal contamination which may be occur during slaughtering, evisceration and transportation (Emswiler et al., 1976; Hamdy et al., 1989; Rice et al., 1997).

Coliform is a group of bacteria inhabit the intestinal tract of worm blooded animals including man. Some species of them are opportunistic pathogens responsible for a wide range of infections while many other species of them are normally free living saprophytic. These bacteria are Gram-negative, aerobic and facultatively anaerobic bacteria, non spore forming and rod shaped, motile by flagella except Klebsiella (non motile), capable of fermenting lactose with the production of acid and gas includes Escherichia coli and species from the genera Escherichia, Klebsiella, Enterobacter, Serratia and Citrobacter (Greenberg and Hunt, 1985; FAO, 1992; Hitchins et al., 1998; FDA 2002).

Due to the heating process was not enough to ensure the safe eating of minced meat (Bayhan et al., 1990), so a lack of good sanitary practices in the production of minced meat may results in a meat of less keeping quality, increase the possibility of spoilage and causing a major health problem (Emswiler et al., 1976; Lochowich, 1978).

The health problem of coliform group depends upon the production of different toxin and colonization factors. The enterotoxigenic strains of Klebsiella, Escherichia, Enterobacter, 
Serratia and Citrobacter have been isolated from infants and children with acute gastroenteritis. These toxins are heat labile and heat stable types and have other properties in common with Escherichia coli toxins. The endotoxins of most coliforms show a bacteraemia in human characterized by fever, vital organs hypoperfusion, depletion of complement, hypotension, irreversible shock and death. Coliforms rarely cause extra-intestinal diseases as bacteraemia and meningitis unless host defense are compromised (Guentzel, 1982; APHA, 1984).

The most virulent and major enteric pathogenic group particularly in developing countries was Enterovirulent Escherichia coli group (EEC) which implicated in food born illness and includes enterotoxigenic Escherichia coli (ETEC), enteropathogenic Escherichia coli (EPEC), enterohemorrhagic Escherichia coli (EHEC), enteroinvasive Escherichia coli (EIEC) (Hitchins et al., 1998; FDA, 2002). These groups have been incriminated in many cases of food borne disease outbreaks, travelers' diarrhea, infantile diarrhea and colibacillosis in adults. There are two forms of the disease which differ clinically from each other to some degree. The first form caused by enteropathogenic strain, is characterized by excessive loss of fluid from profuse diarrhea (Cholera like syndrome) (Pickering, 1986; Nataro and Kaper, 1998). The second form tend to reflect toxins, heat stable toxin (ST) or heat labile toxin (LT) leading to food poisoning, possible accompanied by nausea, fever, abdominal cramps, vomiting, watery or bloody diarrhea, hemorrhagic colitis, hemolytic uremic syndrome and thrombocytopenic purpura (Karmali, 1989; Reed, 1994; Acheson et al., 1996; Ward et al., 1997).

Thus the main purpose of this work was undertaken to evaluate the effect of thermal processing on coliforms in minced beef besides the study of their public health significance in Port-Said city.

\section{MATERIALS and METHODS}

\section{1: Samples collection:}

A total of 50 apparently healthy samples of minced beef were randomly collected from butcher's shops from Port-Said city. Each individual sample (250 g) was placed separately into sealed sterile plastic bag, thoroughly identified and delivered to the laboratory in a refrigerated container at $4{ }^{\circ} \mathrm{C}$. All specimens were prepared, treated and examined within 4 hours of collection. The samples were divided into 2 parts; the $1^{\text {st }}$ part weight $50 \mathrm{~g}$ directed to counting, isolation and identification of coliforms and Escherichia coli. The $2^{\text {nd }}$ part $(200 \mathrm{~g})$ was 
thermally treated according to the approved processing technique before the bacteriological examination.

\section{2: Bacteriological examination:}

\section{2-1: Preparation of the samples:}

A representative $50 \mathrm{~g}$ sample of minced beef (fresh or thermally treated) were taken aseptically and homogenized in $450 \mathrm{ml}$ bufferfield's phosphate buffer and blend for $2 \mathrm{~min}$. at 10000-12000 rpm. Then tenfold serial dilution was prepared using bufferfield's phosphate buffer till dilution $10^{5}$ according to FAO (1992).

\section{2-2: Presumptive test for coliforms:}

Three tubes each containing $10 \mathrm{ml}$ of sterile lauryl tryptose broth (LT) with Durham's tubes, were inoculated with $1 \mathrm{ml}$ from each of the original dilution. Inoculated tubes were thoroughly mixed before being incubated in a thermostatically controlled incubator at $35^{\circ} \mathrm{C}$ for 48 hours. The inspection was done after 24 and 48 hours incubation for positive gas production (FAO, 1992).

\section{2-3: Probable number of total coliforms:}

Gently agitate each positive LT tube and transfer loopful of suspension to tube of brilliant green bile broth $2 \%$ (BGB) containing inverted Durham's tube. All broth tubes were incubated at $35{ }^{\circ} \mathrm{C}$ for $48 \pm 2 \mathrm{hr}$ and examined for gas production. Enumeration of total coliforms was applied by using table of most probable number (MPN) based on combination of confirmed gassing LT tubes for 3 consecutive dilutions.

\section{2-4: Isolation of total coliforms:}

Streak loopful of suspension from gassing LT tube to xylose lysine desoxycholate agar (XLD) and incubate at $35^{\circ} \mathrm{C}$ for $18-24 \mathrm{hr}$ according to FAO (1992).

\section{2-5: Probable number of fecal coliforms:}

Gently agitate each gassing LT tube and transfer loopful of suspension to tube of EC medium containing inverted Durham's tube. All broth tubes were incubated at $45.5 \pm 0.2^{\circ} \mathrm{C}$ for $48 \pm 2 \mathrm{hr}$. The tubes were examined at $24 \mathrm{hr}$ for positive gas production and re-incubate the negative tube for additional $24 \mathrm{hr}$ and examined $2^{\text {nd }}$ time for gas production. Enumeration of fecal coliforms was applied by using table of most probable number (MPN) based on proportion of confirmed gassing EC medium tubes for 3 consecutive dilutions.

\section{2-6: Isolation of fecal coliforms:}

Streak loopful of suspension from gassing EC medium tubes to xylose lysine desoxycholate agar (XLD) and incubate at $35^{\circ} \mathrm{C}$ for $18-24$ hr according to FAO (1992). 


\section{2-7: Enumeration of Escherichia coli:}

Streak loopful of suspension from gassing EC medium tubes to L-EMB (Levine's Eosin-Methylene Blue) agar plate and incubate at $35^{\circ} \mathrm{C}$ for $18-24 \mathrm{hr}$. Then examined the plate for the typical Escherichia coli (dark center with or without metallic sheen). Enumeration of Escherichia coli were applied by using table of MPN based on proportion of EC medium tubes in 3 consecutive dilutions which shown to contain Escherichia coli according to FAO (1992).

\section{2-8: Biochemical identification of the isolates:}

Pick three typical colonies from each agar plate and transfer to plate count agar (PCA) slants tube and incubate at $35^{\circ} \mathrm{C}$ for $18-24 \mathrm{hr}$ according to FAO (1992). All PCA slants were directed to morphological and biochemical identification according to Brenner (1984); Holt et al. (1994) and Farmer (1995).

\section{3: Experimental thermal processing:}

The $2^{\text {nd }}$ part $(200 \mathrm{~g})$ was divided into 2 parts $(100 \mathrm{~g}$ for each part), one part for the conventional roasting technique and the other for pan frying technique.

\section{4- Statistical methods}

Minimum, maximum, mean, standard deviation and standard error of mean and frequency distribution were used to describe data. Ttest was used to evaluate the significant effect of the different methods of thermal processing on the total and fecal coliforms and Escherichia coli. $\mathrm{P}$ value was considered significant if less than 0.05 and 0.01 at $95 \%$ and $99 \%$ respectively. These tests were analyzed using the Statistical Package for Social Scientists (SPSS) for windows 12.0 (SPSS Inc., Chicago, IL, and USA).

\section{RESULTS}

Table 1: Statistical analytical results of the total coliform, fecal coliform and Escherichia coli counts (MPN/g) recovered from fresh and thermal processed minced beef.

\begin{tabular}{|c|c|c|c|c|c|c|c|c|c|c|c|}
\hline & & & \multicolumn{3}{|c|}{ Total coliform in minced beef } & \multicolumn{3}{|c|}{ Fecal coliform in minced beef } & \multicolumn{3}{|c|}{ Escherichia coli in minced beef } \\
\hline & & & Fresh & Roasting & $\begin{array}{c}\text { Pan } \\
\text { frying }\end{array}$ & Fresh & Roasting & $\begin{array}{c}\text { Pan } \\
\text { frying }\end{array}$ & Fresh & Roasting & Pan frying \\
\hline \multirow{6}{*}{ 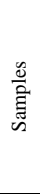 } & \multirow{2}{*}{$\begin{array}{l}\text { Tot } \\
\text { al }\end{array}$} & No. & 50 & 50 & 50 & 50 & 50 & 50 & 50 & 50 & 50 \\
\hline & & $\%$ & 100.00 & 100.00 & 100.00 & 100.00 & 100.00 & 100.00 & 100.00 & 100.00 & 100.00 \\
\hline & \multirow{2}{*}{$\begin{array}{l}(\mathrm{N} \\
\mathrm{D})\end{array}$} & No. & 0.00 & 9 & 18 & 0.00 & 13 & 20 & 17 & 25 & 33 \\
\hline & & $\%$ & 0.00 & 18.00 & 36.00 & 0.00 & 26.00 & 40.00 & 34.00 & 50.00 & 66.00 \\
\hline & \multirow{2}{*}{ (D) } & No. & 50 & 41 & 32 & 50 & 37 & 30 & 33 & 25 & 17 \\
\hline & & $\%$ & 100 & 82.00 & 64.00 & 100 & 74.00 & 60.00 & 66.00 & 50.00 & 34.00 \\
\hline
\end{tabular}




\begin{tabular}{|c|l|l|l|l|l|l|l|l|l|l|}
\hline \multirow{3}{*}{$\begin{array}{c}\text { Statistic for } \\
\text { the counts } \\
\text { of (D) } \\
\text { samples }\end{array}$} & Min. & $4.0 \times 10^{1}$ & $3.0 \times 10^{1}$ & $3.0 \times 10^{1}$ & $3.0 \times 10^{1}$ & $3.0 \times 10^{1}$ & $3.0 \times 10^{1}$ & $4.0 \times 10^{1}$ & $3.0 \times 10^{1}$ & $3.0 \times 10^{1}$ \\
\cline { 2 - 11 } & Max. & $4.6 \times 10^{4}$ & $4.6 \times 10^{3}$ & $2.4 \times 10^{3}$ & $4.6 \times 10^{3}$ & $1.5 \times 10^{3}$ & $7.5 \times 10^{2}$ & $2.4 \times 10^{3}$ & $1.1 \times 10^{3}$ & $1.1 \times 10^{2}$ \\
\cline { 2 - 12 } & Mean & $4.6 \times 10^{3}$ & $1.5 \times 10^{3}$ & $5.8 \times 10^{2}$ & $1.1 \times 10^{3}$ & $5.1 \times 10^{2}$ & $2.6 \times 10^{2}$ & $5.8 \times 10^{2}$ & $2.1 \times 10^{2}$ & $4.8 \times 10^{1}$ \\
\cline { 2 - 11 } & S.D. & $1.1 \times 10^{3}$ & $2.7 \times 10^{2}$ & $1.0 \times 10^{2}$ & $1.8 \times 10^{2}$ & $7.9 \times 10^{1}$ & $4.2 \times 10^{1}$ & $9.8 \times 10^{1}$ & $5.0 \times 10^{1}$ & $0.6 \times 10^{1}$ \\
\hline
\end{tabular}

$\mathrm{ND}=$ Non-Detectable $(<30) . \quad \mathrm{D}=$ Detectable $(>30) . \quad \mathrm{MPN}=$ Most Probable Number

Min. $=$ Minimum. Max. $=$ Maximum. $\mathrm{SE}=$ Standard Error $\mathrm{SD}=$ Standard Deviation .

Table 2: Frequency distribution of the examined fresh and thermal processed minced beef based on their total coliform, fecal coliform and Escherichia coli counts ( $\mathrm{n}=50$ of each).

\begin{tabular}{|c|c|c|c|c|c|c|c|c|c|c|c|c|c|c|c|c|c|c|}
\hline \multirow{3}{*}{$\begin{array}{l}\text { Count } \\
\text { range }\end{array}$} & \multicolumn{6}{|c|}{ Total coliform in minced beef } & \multicolumn{6}{|c|}{ Fecal coliform in minced beef } & \multicolumn{6}{|c|}{ Escherichia coli in minced beef } \\
\hline & \multicolumn{2}{|c|}{ Fresh } & \multicolumn{2}{|c|}{ Roasting } & \multicolumn{2}{|c|}{ Pan frying } & \multicolumn{2}{|c|}{ Fresh } & \multicolumn{2}{|c|}{ Roasting } & \multicolumn{2}{|c|}{ Pan frying } & \multicolumn{2}{|c|}{ Fresh } & \multicolumn{2}{|c|}{ Roasting } & \multicolumn{2}{|c|}{ Pan frying } \\
\hline & No. & $\%$ & No. & $\%$ & No. & $\%$ & No. & $\%$ & No. & $\%$ & No. & $\%$ & No. & $\%$ & No. & $\%$ & No. & $\%$ \\
\hline$<30$ & 0 & 0 & 9 & 18 & 18 & 36 & 0 & 0 & 13 & 26 & 20 & 40 & 17 & 34 & 25 & 50 & 33 & 66 \\
\hline $\begin{array}{ll}30 & - \\
<10^{2} & \end{array}$ & 6 & 12 & 8 & 16 & 7 & 14 & 9 & 18 & 9 & 18 & 10 & 20 & 2 & 4 & 10 & 20 & 15 & 30 \\
\hline $\begin{array}{ll}10^{2} & - \\
<10^{3} & -\end{array}$ & 16 & 32 & 16 & 32 & 18 & 36 & 18 & 36 & 24 & 48 & 20 & 40 & 26 & 52 & 14 & 28 & 2 & 4 \\
\hline $\begin{array}{l}10^{3} \\
<10^{4}\end{array}$ & 15 & 30 & 17 & 34 & 7 & 14 & 23 & 46 & 4 & 8 & 0 & 0 & 5 & 10 & 1 & 2 & 0 & 0 \\
\hline$\geq 10^{4}$ & 13 & 26 & 0 & 0 & 0 & 0 & 0 & 0 & 0 & 0 & 0 & 0 & 0 & 0 & 0 & 0 & 0 & 0 \\
\hline Total & 50 & 100 & 50 & 100 & 50 & 100 & 50 & 100 & 50 & 100 & 50 & 100 & 50 & 100 & 50 & 100 & 50 & 100 \\
\hline
\end{tabular}

$<30=$ Non detectable level.

Table 3: Correlation between total coliform, fecal coliform and Escherichia coli counts based on the examined fresh and thermal processed minced beef ( $\mathrm{n}=50$ of each).

\begin{tabular}{|c|c|c|c|c|c|c|c|c|c|c|c|c|}
\hline & \multicolumn{9}{|c|}{ Minced beef } \\
\hline & & & & \multicolumn{3}{|c|}{ Fresh } & \multicolumn{3}{|c|}{ Roasting } & \multicolumn{3}{|c|}{ Pan frying } \\
\hline & & & & \multicolumn{2}{|c|}{ Coliform } & \multirow{2}{*}{ E. coli } & \multicolumn{2}{|c|}{ Coliform } & \multirow{2}{*}{ E. coli } & \multicolumn{2}{|c|}{ Coliform } & \multirow{2}{*}{ E. colt } \\
\hline & & & & Total & Fecal & & Total & Fecal & & Total & Fecal & \\
\hline \multirow{9}{*}{ 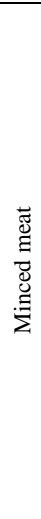 } & \multirow{3}{*}{ 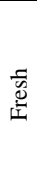 } & \multirow{2}{*}{ Coliform } & Total & ------ & ----- & ----- & $\begin{array}{c}0.044 \\
(*)\end{array}$ & ----- & ------ & $\begin{array}{c}0.001 \\
(* *)\end{array}$ & ----- & ------ \\
\hline & & & Fecal & ----- & ------ & ------ & ------ & $\begin{array}{c}0.043 \\
(*)\end{array}$ & ------ & ------ & $\begin{array}{c}0.001 \\
(* *)\end{array}$ & ------ \\
\hline & & \multicolumn{2}{|l|}{ E. coli } & ------ & ----- & ------ & ------ & ------ & $\begin{array}{c}0.040 \\
(*)\end{array}$ & ------ & ------ & $\begin{array}{c}0.000 \\
(* *)\end{array}$ \\
\hline & \multirow{3}{*}{ 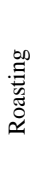 } & \multirow{2}{*}{ Coliform } & Total & $\begin{array}{c}0.044 \\
(*)\end{array}$ & ----- & ------ & ----- & ----- & ------ & $\begin{array}{c}0.031 \\
(*)\end{array}$ & ----- & ----- \\
\hline & & & Fecal & ----- & $\begin{array}{c}0.043 \\
(*)\end{array}$ & ------ & ----- & ----- & ------ & ----- & $\begin{array}{c}0.039 \\
(*)\end{array}$ & ------ \\
\hline & & \multicolumn{2}{|l|}{ E. coli } & ----- & ----- & $\begin{array}{c}0.040 \\
(*)\end{array}$ & - & ----- & ------ & ------ & ------ & $\begin{array}{c}0.044 \\
(*) \\
\end{array}$ \\
\hline & \multirow{3}{*}{$\begin{array}{l}\stackrel{\infty}{\leftrightarrows} \\
\stackrel{\Xi}{\Xi} \\
\stackrel{\Xi}{\Xi}\end{array}$} & \multirow{2}{*}{ Coliform } & Total & $\begin{array}{c}0.001 \\
(* *)\end{array}$ & -. & ------ & $\begin{array}{c}0.031 \\
(*) \\
\end{array}$ & ------ & ------ & ------ & ------ & ------ \\
\hline & & & Fecal & ----- & $\begin{array}{c}0.001 \\
(* *)\end{array}$ & ------ & ----- & $\begin{array}{c}0.039 \\
(*)\end{array}$ & ------ & ------ & ------ & ------ \\
\hline & & \multicolumn{2}{|l|}{ E. coli } & ----- & ----- & $\begin{array}{c}0.000 \\
(* *)\end{array}$ & ----- & ----- & $\begin{array}{c}0.044 \\
(*)\end{array}$ & ----- & ----- & ------ \\
\hline
\end{tabular}

$(* *)=$ Highly significant correlation at $<0.01$ (99\% confidence) by using t-test (Paired system test).

$(*)=$ Significant correlation at $<0.05$ ( $95 \%$ confidence) by using t-test (Paired system test).

E. coli $=$ Escherichia coli 
Fig. (1): Effect of thermal processing on total coliform, fecal coliform and Escherichia coli counts (MPN/g) recovered from minced beef.

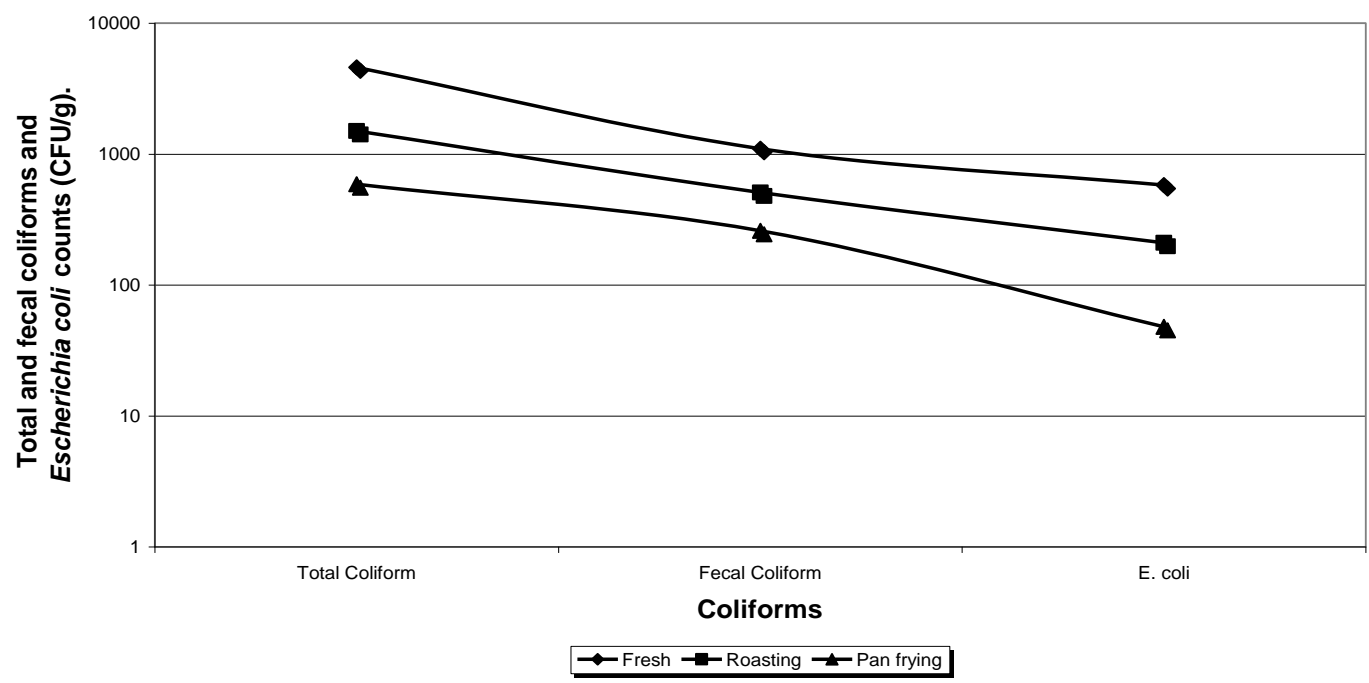

Table 4: Incidence of coliforms isolates recovered from fresh and thermal processed minced beef.

\begin{tabular}{|c|c|c|c|c|c|c|c|c|c|c|c|}
\hline \multirow{3}{*}{\multicolumn{3}{|c|}{$\begin{array}{c}\text { Incidence of coliforms } \\
\text { organisms }\end{array}$}} & \multicolumn{9}{|c|}{ Minced beef } \\
\hline & & & \multicolumn{3}{|c|}{ Total coliform } & \multicolumn{3}{|c|}{ Fecal coliform } & \multicolumn{3}{|c|}{ Escherichia coli } \\
\hline & & & Fresh & Roasting & $\begin{array}{c}\text { Pan } \\
\text { frying }\end{array}$ & Fresh & Roasting & $\begin{array}{c}\text { Pan } \\
\text { frying }\end{array}$ & Fresh & Roasting & $\begin{array}{c}\text { Pan } \\
\text { frying }\end{array}$ \\
\hline \multirow{2}{*}{\multicolumn{2}{|c|}{ Examined samples }} & No. & 50 & 50 & 50 & 50 & 50 & 50 & 50 & 50 & 50 \\
\hline & & $\%$ & 100 & 100 & 100 & 100 & 100 & 100 & 100 & 100 & 100 \\
\hline \multirow{2}{*}{\multicolumn{2}{|c|}{ Positive samples }} & No. & 50 & 41 & 32 & 50 & 37 & 30 & 33 & 25 & 17 \\
\hline & & $\%$ & 100 & 82.00 & 64.00 & 100 & 74.00 & 60.00 & 66.00 & 50.00 & 34.00 \\
\hline \multirow{2}{*}{\multicolumn{2}{|c|}{ Total isolates }} & No. & 88 & 54 & 32 & 63 & 44 & 31 & 33 & 25 & 17 \\
\hline & & $\%$ & 100.00 & 100.00 & 100.00 & 100.00 & 100.00 & 100.00 & 100.00 & 100.00 & 100.00 \\
\hline \multirow{12}{*}{ 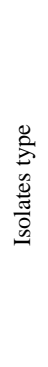 } & \multirow{2}{*}{$\begin{array}{l}\text { 1-Escherichia } \\
\text { coli }\end{array}$} & No. & 33 & 25 & 17 & 33 & 25 & 17 & 33 & 25 & 17 \\
\hline & & $\%$ & 37.5 & 46.30 & 53.13 & 52.38 & 56.82 & 54.84 & 100.00 & 100.00 & 100.00 \\
\hline & \multirow{2}{*}{$\begin{array}{l}\text { 2-Enterobacter } \\
\text { cloacae }\end{array}$} & No. & 19 & 11 & 9 & 19 & 11 & 9 & ------ & ------ & ------ \\
\hline & & $\%$ & 21.59 & 20.37 & 28.13 & 30.16 & 25.00 & 29.03 & ------ & ------ & ------ \\
\hline & \multirow{2}{*}{$\begin{array}{l}\text { 3-Enterobacter } \\
\text { aerogenes }\end{array}$} & No. & 11 & 8 & 5 & 11 & 8 & 5 & ------ & ------ & ------ \\
\hline & & $\%$ & 12.5 & 14.81 & 15.63 & 17.46 & 18.18 & 16.13 & ------ & ------ & ------ \\
\hline & \multirow{2}{*}{$\begin{array}{l}\text { 4-Citrobacter } \\
\text { freundii }\end{array}$} & No. & 12 & 5 & 1 & ------ & $\begin{array}{l}----- \\
-\end{array}$ & ------ & ------ & ------ & ------ \\
\hline & & $\%$ & 13.64 & 9.26 & 3.13 & ------ & ------ & ------ & ------ & ------ & ------ \\
\hline & \multirow{2}{*}{$\begin{array}{l}\text { 5-Citrobacter } \\
\text { koseri }\end{array}$} & No. & 8 & 3 & 0 & ----- & ------ & ------ & ------ & ------ & ------ \\
\hline & & $\%$ & 9.09 & 5.56 & 0.00 & ------ & ------ & ------ & ------ & $\begin{array}{l}----- \\
\end{array}$ & ------ \\
\hline & \multirow{2}{*}{$\begin{array}{l}\text { 6-Serratia } \\
\text { marcescens }\end{array}$} & No. & 5 & 2 & 0 & ----- & ----- & ----- & ----- & ------ & ------ \\
\hline & & $\%$ & 5.68 & 3.70 & 0.00 & ------ & ------ & ----- & ------ & ------ & ------ \\
\hline
\end{tabular}




\section{DISCUSSION}

Members of the coliform groups are referred as general indicator microorganisms to measure the potential presence of enteric pathogens (for example Escherichia coli) in foods, besides the measuring of fecal contamination of the food products and the sanitary condition in the food-processing environment (Greenberg and Hunt, 1985; APHA, 1992; FAO, 1992). The possibility of food health problem by coliforms depending upon the number, types and the virulent of these pathogens whereas, the higher the number, the greater the possibility of pathogenic organisms being present (FAO, 1992).

The given results in Table (1) revealed that the incidences of positive fresh minced beef samples for total and fecal coliforms and Escherichia coli were 100\% (50), 100\% (50) and 66\% (33) respectively. The incidence of positive samples for coliforms was higher than the results recorded by (Kaloianov et al., 1987; Willshaw et al., 1993; Heredia et al., 2001; Tanios et al., 2002; Cohen et al., 2006) but that of Escherichia coli was lower than those recorded by (Heredia et al., 2001). The high incidence of positive samples may be attributed to the unsanitary conditions during the production and manufactured of minced beef (Wilson, 2001). The mean values of the total and fecal coliforms and Escherichia coli counts in fresh minced meat were $4.6 \mathrm{X} \mathrm{10}^{3}, 1.1 \mathrm{X}$ $10^{3}$ and $5.8 \times 10^{2}(\mathrm{MPN} / \mathrm{g})$ in the examined fresh minced beef respectively (Table 1). These results agreed with the results recorded by (Rogers and McCleskey, 1957; Küpeli, 1996) but lower than the coliforms results recorded by (Yilmaz et al., 2002a). On the other hand our results were higher than the results recorded by (Kaloianov et al., 1987; Yilmaz et al., 2002; Firstenberg et al., 2004). The high figures of our results may be attributed to contamination of meat during slaughtering, evisceration and transportation (Hamdy et al., 1989), bad microbiological quality and heavy load coliform of trimming and cuts of beef (Emswiler et al., 1976; Bayhan et al., 1990), unsanitary conditions during the manufacture (APHA 1992; Wilson, 2001) and after manufacture as bad handling and packaging of minced beef (Yilmaz et al., 2005; Cohen et al., 2006), besides long chilling storage or holding of the minced beef at an inappropriate temperature (Kandeepan and Biswas, 2005; Yilmaz et al., 2005). Meanwhile the higher counts of fecal coliform and Escherichia coli may be attributed to recent fecal contamination (Caplenas and Kanarek, 1984; Greenberg and Hunt, 1985; APHA, 1992; FDA, 2002) from contaminated or infected cattle (Rice et al., 1997) with the upper mention causes. 
The presented results in Table (2) showed that the frequency distribution of the total and fecal coliforms and Escherichia coli within the range $30-<10^{4}$ were $74 \% \quad(37), 100 \% \quad(50)$ and $66 \%$ (33) respectively but $26 \%$ (13) of the fresh minced beef showed the total coliforms with the range $\geq 10^{4} \mathrm{MPN} / \mathrm{g}$ and $34 \%$ (17) of the examined fresh minced beef had non detectable levels (< $30 \mathrm{MPN} / \mathrm{g}$ ) for Escherichia coli. These results were higher than the results recoded by (Surkiewicz et al., 1975; Firstenberg et al., 2004). Higher results may be attributed to heavy load and high initial counts of coliforms and Escherichia coli (Bayhan et al., 1990) and unsanitary conditions during the manufacture of minced beef with long chilling storage (Wilson, 2001).

Regarding to the effect of thermal processing on total and fecal coliforms and Escherichia coli presented in Table (1) It is evident that the incidences of positive roasting minced beef samples for total and fecal coliforms and Escherichia coli were 82\% (41), 74\% (37) and 50\% (25) respectively while in case of the examined pan frying minced beef the incidence were decreased to $64 \%$ (32), 30\% (30) and 34\% (17) respectively. On the other hand the mean values of the total and fecal coliforms and Escherichia coli counts were $1.5 \times 10^{3}, 5.1 \times 10^{2}$ and 2.1 $\mathrm{X} 10^{2} \mathrm{MPN} / \mathrm{g}$ for roasting minced beef respectively while that of pan frying minced beef were reduced to $5.8 \times 10^{2}, 2.6 \times 10^{2}$ and $4.8 \times 10^{1}$ $\mathrm{MPN} / \mathrm{g}$ under effect of roasting technique respectively.

Also the thermal processing effect presented in Table (2) revealed that the percentage of the examined samples showed non detectable levels (<30 MPN/g) for total coliform, fecal coliform and Escherichia coli under effect of roasting technique were $18 \%$ (9), 26\% (13) and $50 \%$ (25) respectively, while under the effect of pan frying technique the percentage of the examined samples showed non detectable levels (<30 MPN/g) for total coliform, fecal coliform and Escherichia coli were increased to $36 \%$ (18), $40 \%$ (20) and $66 \%$ (33) respectively. On the other hand most of the examined roasting minced beef samples [82\% (41), 74\% (37) and 50\% (25)] had a rang of 30 $<10^{4} \mathrm{MPN} / \mathrm{g}$ for total and fecal coliforms and Escherichia coli while that of pan frying minced beef samples [50\% (25), 60\% (30) and 34\% (17)] were reduced to $30-<10^{3} \mathrm{MPN} / \mathrm{g}$ respectively. These results with Fig (1) showed that the heat processing either roasting or pan frying technique reduce the total and fecal coliforms and Escherichia coli counts to a different levels. This reduction effect agrees with the result recorded by (Delchev et al., 1978; Jay, 1978; Zahra et al., 1985; 
Desmarchelier and Grau, 1997; Yilmaz et al., 2005) but this reduction was impossible to eliminate all forms of coliforms (Jay, 1978).

Statistically by using t-test, showed a highly significant relationship between the counts of each of total and fecal coliforms and Escherichia coli recovered from fresh minced beef samples with that of the pan frying samples but roasting technique showed a significant relationship between them (Table 3). On the other hand the relationship between pan frying and roasting technique showed a significant relationship. This mean pan frying technique was more effective and more efficient than roasting technique in reduction effect (Yilmaz et al., 2002).

The obtained results in Table (4) showed that the number of total and fecal coliforms and Escherichia coli isolates of fresh minced beef were 88,63 and 33 isolates respectively. In case of roasting technique, these isolates were reduced to 54, 44 and 25 for total and fecal coliforms and Escherichia coli respectively while in case of pan frying minced beef samples the isolates were more reduced to 32,31 and 17 isolates respectively. The coliforms organisms recovered from the examined samples were identified as Escherichia coli, Enterobacter cloacae, Enterobacter aerogenes, Citrobacter freundii, Citrobacter koseri and Serratia marcescens. The main and important isolate found in fresh and treated samples was Escherichia coli. On the other hand Citrobacter freundii, Citrobacter koseri and Serratia marcescens found only in total coliform and this may be attributed to that these group of microorganisms can not tolerate high temperature but fecal coliform and Escherichia coli can tolerate and considered thermotolerant organisms (Caplenas and Kanarek, 1984). The reduction in the number of isolates was more in pan frying than in roasting technique and this agrees with the result recorded by (Zahra et al., 1985) who showed that coliforms were easily killed (Jay, 1978) and decreased markedly after heat treatment but heating process was not enough to ensure the safe eating quality (Bayhan et al., 1990) and impossible to eliminates all forms of coliforms (Jay, 1978). The variation between our result and the other results recorded by (Yilmaz et al., 2005) may attributed to the variation in season and locality (Cohen et al., 2006) and the high initial counts of coliforms found in minced beef (Zahra et al., 1985).

The safety of minced meat associated with the keeping quality of meat cuts, sanitary condition during handling, fabrication, packaging, equipment and utensils used and time/temperature of storage (Emswiler et al., 1976; APHA, 1992). The endotoxins of coliform groups, heat labile and heat stable types specially that of Escherichia coli toxins 
(Pickering, 1986; Hitchins et al., 1998) with the undercooked or improperly cooked minced beef and cross and post cooking contamination by these microorganisms (Guentzel, 1982; Ward et al., 1997; Cohen et al., 2006) results in a major health problem to the consumers. Consequently the presence of large number of coliforms in foods is highly undesirable but it would be almost impossible to eliminate all forms of coliform (Jay, 1978). In conclusion, to increase the shelf life and the safety of minced meat and decrease their coliforms loads and prevention the infections by these microorganisms to the consumers, a groups of measurement should be attempt such as good and strictly hygienic measurement pre and during slaughtering, evisceration and transportation with the avoidances of the contamination of meat from other infected or contaminated animals. Also personal hygiene and removal the source of pollution as fecal contamination and sewage water with good sanitary condition during handling, grinding and mixing processes besides the equipment and utensils used in fabrication produce a minced beef of good keeping quality. The refrigeration (below $4^{\circ} \mathrm{C}$ ) and good time/temperature storage with sufficiently cooking of minced meat and prevent the post cooking cross contamination and prohibiting people who are ill from working in food operations and strictly prevention the consumption of insufficient cooked minced meat specially in compromised hosts reduce the consumers health problem.

\section{REFERENCES}

Acheson, D.; Lincicome, L.; Breucher, S. and Keusch, G. (1996): Detections of Shiga-like toxin-producing E. coli in ground beef and milk by commercial Enzyme immunoassay. J. Food Prot., 59 (4): 344-349.

APHA "American Public Health Association" (1984): Compendium of Methods for the Microbiological Examination of Foods, $2^{\text {nd }}$ ed. Amer. Public Health Assn., Washington, D.C., p. 99-111.

APHA "American Public Health Association" (1992): Compendium of Methods for the Microbiological Examination of Foods, $3^{\text {rd }}$ ed. Amer. Public Health Assn., Washington, D.C.

Bayhan, A.; Abbasoglu, U. and Yentür, G. (1990): Ankara'da tüketilen izgara köftelerinin halk sagligi yönünden arastirilmasi. Gida, 15 (4): $235-243$ 
Brenner, D. (1984): Enterobacteriaceae, p. 408-420. In N. R. Krieg and J. G. Holt (ed.), Bergey's manual of systemic bacteriology, Vol. I. Williams \& Wilkins, Baltimore, MD.

Caplenas, N. and Kanarek, M. (1984): Thermotolerant non-fecal source Klebsiella pneumoniae: Validity of the fecal coliform test in recreational waters. Am. J. Public Health. 74: 1273-1275

Cohen, N.; Ennaji, H.; Hassa, M. and Karib, H. (2006): The bacterial quality of red meat and offal in Casablanca (Morocco). Mol. Nutr. Food Res. 50 (6): 557-562.

Delchev, K.; Iordanov, I.; Savov, D.; Vaptsarova, M. and Dimitrov, I. (1978): Resistance of E. coli and bacteria of the genus Proteus to the thermal processing of perishable meat products. Vet. Med. Nauki. 15 (6): 29-35.

Desmarchelier, P. and Grau, F. (1997): Escherichia coli. Foodborne Microorganisms of Public Health Significance. A.D. Hocking, G. Arnold, I. Jenson, K. Newton and P. Shuterland (ed.). pp 231-264-. Australian Institute of Food Science and Technology Inc., Sydney, Australia.

Emswiler, B.; Pierson, C. and Kotula, A. (1976): Bacteriological quality and shelf life of Ground beef. Applied and Environmental Microbiology. Vol. 31, No. 6, pp. 826-830.

FAO "Food and Agriculture Organization" (1992): Escherichia coli and other coliforms. Manual of Food Quality Control. 4.Rev.1Microbiological Analysis. Food and Agriculture Organization Of The United Nation, Rome, Italy, Chap. 3 pp 13-26.

Farmer, J. (1995): Enterobacteriaceae: introduction and identification. In Manual of Clinical Microbiology, $6^{\text {th }}$ Edn (Murray. P. R., Baron, E. J., Pfaller, M. A., Tenover, F. C. \& Yolken, R. H., Eds), pp. 438-439. ASM Press, Washington, Dc.

FDA "Food and Drug Administration" (2002): Enumeration of Escherichia coli and the coliform bacteria. Bacteriological Analytical Manual Online. Food and Drug Administration, Center for Food Safety \& Applied Nutrition. Chap. 4

Firstenberg, E. Foti, R., McDougal, S. and Beck, S. (2004): Performance comparison of the Bio Sys optical assay and the violet red bile agar methods for detecting coliforms in food products. J. Food Prot. 67(12): 2760-2766.

Greenberg, A. and Hunt, D. (1985): Laboratory Procedures for the Examination of Seawater and Shellfish, $5^{\text {th }}$ ed. The American Public Health Association, Washington D.C. 
Guentzel, N. (1982): Escherichia, Klebsiella, Enterobacter, Serratia, Citrobacter and Proteus. Chap. 26. In Medical Microbiology, $4^{\text {th }}$ ed. Online. Samuel baron, M. D. (Ed.). University of Texas Medical Branch. Washington D.C.

Hamdy, M.; EL-Mossalami, M. and Zeinab, M. Niazi (1989): Enteropathogenic Escherichia coli (EEC) in slaughtered cattle at a modern abattoir. Vet. Med. J. Giza, 37 (1): 9-23.

Heredia, N.; Garcia, S.; Rojas, G. and Salazar, L. (2001): Microbiological condition of ground meat retailed in Monterrey. Mexico. J. Food Prot. 64(8): 1249-1251.

Hitchins, A.; Feng, P.; Watkins, W.; Rippey, S. and Chandler, L. (1998): Escherichia coli and the coliform bacteria. Ch. 4. In food and Drug Administration, Bacteriology Analytical Manual $8^{\text {th }}$ ed. (Revision, A.), CCD-Rom version). R. L. Merker (Ed.). AOAC International, Gaithersburg MD

Holt, J.; Krieg, N.; Smeath, P.; Staley, J. and Williams, S. (1994): Bergey's manual of determinative bacteriology, $9^{\text {th }}$ ed. Williams \& Wilkins, Baltimore, MD.

Jay, J. (1978): Modern Food Microbiology, $2^{\text {nd }}$ Ed. D. Van Nostrand Company, New York.

Kalalou, I.; Faid, M. and Ahami, A. (2004): Extending shelf life of fresh minced camel meat at ambient temperature by Lactobacillus delbrueckii subspecies delbrueckii. Electronic Journal of Biotechnology Vol. 7 No. 3.

Kaloianov, I.; Monov, G.; Ionova, I.; Kunev, Z. and Petkov, R. (1987): Hygienic research on meat-dressing shops and enterprises. Vet. Med. Nauki. 24(7): 49-58.

Kandeepan, G. and Biswas, S. (2005): Effect of low temperature presentation on microbial and sensory quality of buffalo meat. Livestock Research for Rural Development 17(11) online edition.

Karmali, M. (1989): Infection by verotoxin-producing Escherichia coli. Clin. Microbiol. Rev., 2: 15-38

Küpeli, V. (1996): Yaprak Donerin Kimyasal Bileşimi ve Mikrobiyolojik Kalitesi. Y. L. Tezi, Atatürk Uni. Zir. Fak. Erzurum. (Turkish).

Lochowich, R. (1978): Microbiology of meat, p. 230-286. In J. F. Price and B.F. Schweigert (ed.), The science of meat and meat products. W. H. Freeman and Co., San Francisco.

Nataro, J. and Kaper, J. (1998): Diarrheagenic Escherichia coli. Clin. Microbiol. Rev. 11:132-201. 
Pickering, L. (1986): Gastroenteritis due to enteropathogenic, enterotoxigenic and invasive Escherichia coli. A Review. Am. J. Med. Tech. 45:787-792.

Reed, G. (1994): Food borne illness (Part 8): Escherichia coli. Dairy, Food and Environmental San. 14 (6): 329-330.

Rice, D.; Ebel, E.; Hancock, D.; Besser, T.; Herriott, D. and Carpenter, L. (1997): Escherichia coli O157 in cull dairy cows on farm and at slaughter. J. Food Prot., 60 (11): 1386-1387.

Rogers, R. and McCleskey, C. (1957): Bacteriological quality of ground beef in retail markets, Food Technol. (Chicago) 11: 318-320.

Surkiewicz, B.; Harris, M.; Elliott, R.; Macaluso, J. and Strand, M. (1975): Bacteriological survey of raw beef patties produced at establishments under federal inspection. Appl. Microbiol. 29: 331-334.

Tanios, A.; Shaaban, A.; Abd EL-Aty Ebtehal, A., and El-Sheronoby, $R$. (2002): Serological features of pathogenic E. coli in meat and meat products. J. Egypt. Vet. Med. Ass. 62(3): 245-253.

Ward, D.; Bernard, D.; Collette, R.; Kraemer, D.; Hart, K.; Price, R. and Otwell, S. (1997): Hazards Found in Seafoods. Appendix III. In HACCP: Hazards Analysis and Critical Control Point Training Curriculum, $2^{\text {nd }}$ ed., p.173-188. UNC-SG-96-02. North Carolina Sea Great. Raleigh NC.

Willshaw, G.; Smith, H.; Roberts, D.; Thirlwell, J.; Cheasty, T. and Rowe, B. (1993): Examination of raw beef products for the presence of verocytotoxin producing Escherichia coli, particularly those of serogroup O157. J. App. Bacteriol., 75: 420-426.

Wilson, P. (2001): Determination of coliforms in foods using violet red bile agar. Canadian Food Inspection Agency CFIA Dartmouth Laboratory. Dartmouth, NS B2Y $3 Z 7$.

Yilmaz, I.; Arici, M. and Gümü, T. (2005): Changes of microbiological quality in meatballs after heat treatment. European Food Research and Technology. Vol. 221 (3-4): 281-283

Yilmaz, I.; Yetim, H. and Ockerman, H. (2002): The effect of different cooking procedures on microbiological and chemical quality characteristics of Tekirdag meatballs. Nahrung 46 (4) 276-278.

Zahra, M.; Helmy, Z. and Musleh, R. (1985): Bacteriological flora of meat and meat products. Zentralbl. Mikrobiol. 140(10): 55-58. 
Assiut Vet. Med. J. Vol. 53 No 112 January 2007 